\title{
Multi-Walled Carbon Nanotubes Supported Pd(II) Complexes: A Supramolecular Approach towards Single-Ion Oxygen Reduction Reaction Catalysts
}

\author{
Matteo Savastano ${ }^{1, *,+}\left(\mathbb{D}\right.$, Maurizio Passaponti ${ }^{1,+}{ }^{,}$Walter Giurlani ${ }^{1}{ }^{(\mathbb{C}}$, Leonardo Lari ${ }^{2,3}$, \\ Antonio Bianchi ${ }^{1}$ (D) and Massimo Innocenti ${ }^{1}$ (D) \\ 1 Department of Chemistry "Ugo Schiff", University of Florence, via della Lastruccia 3, 50019 Sesto Fiorentino, \\ Italy; maurizio.passaponti@unifi.it (M.P.); walter.giurlani@unifi.it (W.G.); antonio.bianchi@unifi.it (A.B.); \\ minnocenti@unifi.it (M.I.) \\ 2 Physics Department, University of York, Heslington, York YO10 5DD, UK; leonardo.lari@york.ac.uk \\ 3 The York-JEOL Nanocentre, Helix House, Science Park, Heslington, York YO10 5BR, UK \\ * Correspondence: matteo.savastano@unifi.it \\ + These authors contributed equally.
}

Received: 25 September 2020; Accepted: 20 October 2020; Published: 22 October 2020

\begin{abstract}
Lowering the platinum group metal content of oxygen reduction reaction catalysts is among the most prevalent research focuses in the field. This target is herein approached through supported Pd(II) complexes. Starting from a commercial macrocycle, a new ligand is synthesized, its solution behavior and binding properties briefly explored (potentiometry, UV-Vis) and then used to prepare a new catalyst. A supramolecular approach is used in order to obtain homogeneous decoration of carbon nanotubes surfaces, fostering novel possibilities to access single-ion active sites. The novel catalyst is characterized through X-ray photoelectron spectroscopy and scanning transmission electron microscopy and its promising oxygen reduction reaction performance is evaluated via rotating ring-disk electrode and rotating disk electrode in half-cell studies.
\end{abstract}

Keywords: heterogeneous catalysis; surface adsorption; palladium catalyst; supramolecular interactions; ORR; RRDE; CNTs

\section{Introduction}

Climate change evidence [1], pollution [2], and recent data concerning the improvement of air quality connected with the decrease of human industrial activities during COVID-19 lockdowns [3] are raising the awareness of public opinion on the importance of transitioning to cleaner energy. At the same time, as Mendeleev suggested a long time ago, there are much smarter possible usages for non-renewable resources, such as hydrocarbons, than burning them for energy production.

Fuel cells and hydrogen technology appear as a possible solution: provided that $\mathrm{H}_{2}$ is produced from clean sources, its use as energy vector would be ideal, as its combustion is highly exothermic and produces no waste residuals beyond water [4,5]. Currently, beyond superable pragmatic issues (the conversion of fuel supply chain, safe high-pressure portable tanks for vehicles, etc.) [4,6], technological obstacles are still limiting large scale $\mathrm{H}_{2}$ usage: these mainly include effective electrocatalysts for fuel cell and water hydrolysis which are able to maintain high performances over time at affordable costs [7-9]. Here, we remark on the crucial dependence of most up-to-date solutions on so-called PGM (platinum group metals), which are not only expensive but also, again, finite resources (i.e., not fundamentally better than hydrocarbons to critically rely upon).

How to design a better catalyst? 
This is the question that led chemists and material scientists to explore a plurality of tentative answers. Metal nanoparticles [10-15], non-noble metals [10,11,16], and even metal-free catalysts [16-19] have been proposed, with each of these solutions coming with its own merits and shortcomings.

Our contribution to the field goes in yet another direction. Regardless of which metal we will use as catalyst, if any, it is important to make a strategical use of available resources: reuse and recycle are good things [20], using less is even better. In terms of catalysts, this implies, at its theoretical limit, using a single ion or metal atom as a catalytic active site. The general concept of single-atom catalysts (SACs) has been introduced and discussed elsewhere [21-23]. In the case of Pd, which is the element that we currently focus on (face-centred cubic, lattice constant $3.859 \AA$ ), the difference between supported small nanoparticles (a perfect cubic small NP with a $3.859 \mathrm{~nm}$ side consists of 4000 atoms) and a SAC catalyst, could mean lowering the required amount of Pd of about three orders of magnitude. At market prices above $60 \$ / \mathrm{g} \mathrm{Pd}$, this can, in principle, have a huge impact on the economic feasibility of any catalysts: a crucial aspect for oxygen reduction reaction (ORR).

We make use of supramolecular chemistry and supported metal complexes to achieve this type of catalyst, rather than doping strategies [24-26]. A smart modular design of organic ligands possessing a polyaminic macrocyclic unit for $\mathrm{Pd}(\mathrm{II})$ binding and a grafting unit for non-covalent spontaneous functionalization of graphitic surfaces (activated carbon, multi-walled carbon nanotubes (MWCNT), graphene), bridged by a spacer, allows for relatively easy preparation of heterogenous catalysts in mild conditions (water, r.t., air) [27-30]. Moreover, such an approach could allow for the preparation of catalysts possessing truly identical active sites spread on a surface, while doping strategies generally involve aleatory factors that may lead to statistical results. As we demonstrated in previous studies, MWCNT-supported $\mathrm{Pd}(\mathrm{II})$ complexes prepared with this design can surpass the performances of commercial solid Pt polycrystalline electrode, with incalculable savings in terms of required PGM atoms [24]. The approach is generally valid and it has found application for other catalytic processes, like the $\mathrm{Cu}$-free Sonogashira cross-coupling [27,28]. Moreover, should the field shift towards non-noble metals, the macrocyclic portion of the ligand is changeable to suit the stereoelectronic preferences of different metal ions [31-33]. Should metal-free catalyst instead become popular, this approach can be, and has been, used to graft organic molecules on graphitic surfaces (e.g., for $\mathrm{pH}$-controlled recovery of metal ions and their cyano complexes) $[29,31,34,35]$, thus offering a convenient functionalization method.

As all strategies, ours is not free from challenges. As we take full advantages of a spontaneous self-assembly process for the homogeneous decoration of graphitic surfaces, the adsorbate/adsorbent interactions are neither as strong as covalent bonds found in different approaches nor as resilient as fully inorganic (metal, metal oxides, etc.) materials. This is not an issue for mild temperature ranges (which, in a green perspective, are generally desirable), but ligand/metal complexes desorption has been observed at higher temperatures (e.g., $70{ }^{\circ} \mathrm{C}$, [27]), narrowing the applicability of our catalysts.

While the grafting moiety, a convenient pyrimidine derivative with an extremely electron-deficient character, could, in principle, also be replaced, we tried to improve the stability of our catalysts by adding a second identical pyrimidine moiety for each metal complex in order to achieve a firmer chemisorption. Linear commercial ligands, despite interesting, tend to form metal complexes of various stoichiometry, which complicate the picture and conflict with the idea of single identical catalytic active sites [36]. A more stable catalyst adsorbed via two pyrimidine moieties per metal center has been recently reported for the Sonogashira cross-coupling: no desorption issues were observed; yet, as the complex nature of the non-commercial (and thus sub-optimal, price-wise) polyaminic portion of the ligand offered further binding sites stabilizing $\operatorname{Pd}(0)$ NPs, deactivation still happened over time due to $\operatorname{Pd}(\mathrm{II})$ reduction [28].

Proofs of concept are important, but a rational catalysts design, we believe, should factor in all relevant costs, including those of starting materials. Herein we propose a novel catalyst based on the novel ligand $\mathrm{H}_{3} \mathrm{~L}$ (Figure 1), built around the commercial macrocyclic [9] ane $\mathrm{N}_{3}$ (1,4,7-triazacyclononane) core, featuring three pyrimidine grafting moieties that are bridged by 
simple ethylamine spacers (again from commercial reagents). This prosecutes the course of our investigation while shifting it further towards affordable costs and fostering stronger chemisorption (three grafting moieties).<smiles>Cn1c(NCCN2CCN(CCNc3nc(N)c(N=O)c(=O)n3C)CCN(CCNc3nc(N)c(N=O)c(=O)n3C)CC2)nc(N)c(N=O)c1=O</smiles>

Figure 1. The $\mathrm{H}_{3} \mathrm{~L}$ ligand.

\section{Materials and Methods}

\subsection{Synthesis of $\mathrm{H}_{3} \mathrm{~L}$}

2,2' ,2"-(((1,4,7-triazonane-1,4,7-triyl)tris(ethane-2,1-diyl))tris(azanediyl))tris(6-amino-3-methyl-5nitrosopyrimidin-4(3H)-one $\left(\mathbf{H}_{3} \mathbf{L}\right)$ has been synthetized according to Scheme 1 .

$\mathrm{N}, \mathrm{O}-$ bis(p-toluenesulfonyl)ethanolamine (1) had been previously prepared from commercial ethanolamine and $\mathrm{p}$-toluenesulfonylchloride. Its cyclization afforded $\mathrm{N}$-(p-toluenesulfonyl)aziridine (2) in $85 \%$ yield according to literature procedures [37]. The reaction of [9]ane $\mathrm{N}_{3}$ (3) with three equivalents of 2 in $\mathrm{CH}_{3} \mathrm{CN}$ under $\mathrm{N}_{2}$ atmosphere afforded the tosylated polyamine 4 (N, $\mathrm{N}^{\prime}, \mathrm{N}^{\prime \prime}-((1,4,7$-triazonane-1,4,7-triyl)tris(ethane-2,1-diyl))tris(4-methylbenzenesulfonamide) in high yield $(86 \%)$. Detosylation with concentrated sulfuric acid afforded the hydrogen sulfate salt of the polyamine 5 (2,2', $2^{\prime \prime}$-(1,4,7-triazonane-1,4,7-triyl)triethanamine), which was converted to its free amine form with a Dowex $1 \times 8$ ionic exchange column that was activated with $\mathrm{NaOH}$ (global yield of 5: 79\%) [38]. 5 is then reacted with the pyrimidine precursor 6 . This molecule is accessible from commercial products on a multigram scale [39]. $0.5 \mathrm{~g}$ of $5(1.94 \mathrm{mmol})$ was reacted with $1.15 \mathrm{~g}$ of 6 ( $6.19 \mathrm{mmol}$, i.e., 3.2 equivalents with respect to 5 ) in $500 \mathrm{~cm}^{3}$ of MeOH. After adding solid 6 in small portions within $3 \mathrm{~h}$, the solution is heated to reflux for $1 \mathrm{~h}$. Excess pyrimidine is eliminated by adding five drops of $\mathrm{NH}_{3 \mathrm{aq}}(33 \%)$, which converts it to 2,4-diamino-1-methyl-5-nitroso-6-oxopyrimidine, insoluble in $\mathrm{MeOH}$. After storing overnight in a fridge, the resulting suspension has been filtered, and the $\mathrm{MeOH}$ solution evaporated to dryness under vacuum at r.t. to obtain $\mathbf{H}_{3} \mathbf{L}$ as a deep purple solid compound. Yield $87 \%$.

Elemental analysis calculated for $\mathrm{C}_{27} \mathrm{H}_{42} \mathrm{~N}_{18} \mathrm{O}_{6}: \mathrm{C}, 45,37 ; \mathrm{H}, 5,92 ; \mathrm{N}, 35,27 ; \mathrm{O}, 13,43$. Found: $\mathrm{C}$, 45.1; $\mathrm{H}, 5.6 ; \mathrm{N} 34.9 .{ }^{1} \mathrm{H}$ NMR $\left(\mathrm{D}_{2} \mathrm{O}, \mathrm{pH} 1,25^{\circ} \mathrm{C}, 400 \mathrm{MHz}\right) \delta 3.95(\mathrm{~m}, 6 \mathrm{H}), 3.45(\mathrm{~s}, 9 \mathrm{H}), 3.41(\mathrm{~m}, 12 \mathrm{H})$, $3.36(\mathrm{~m}, 6 \mathrm{H})$.

All of the solvents and reagents were purchased from Sigma-Aldrich (Milan, Italy). 

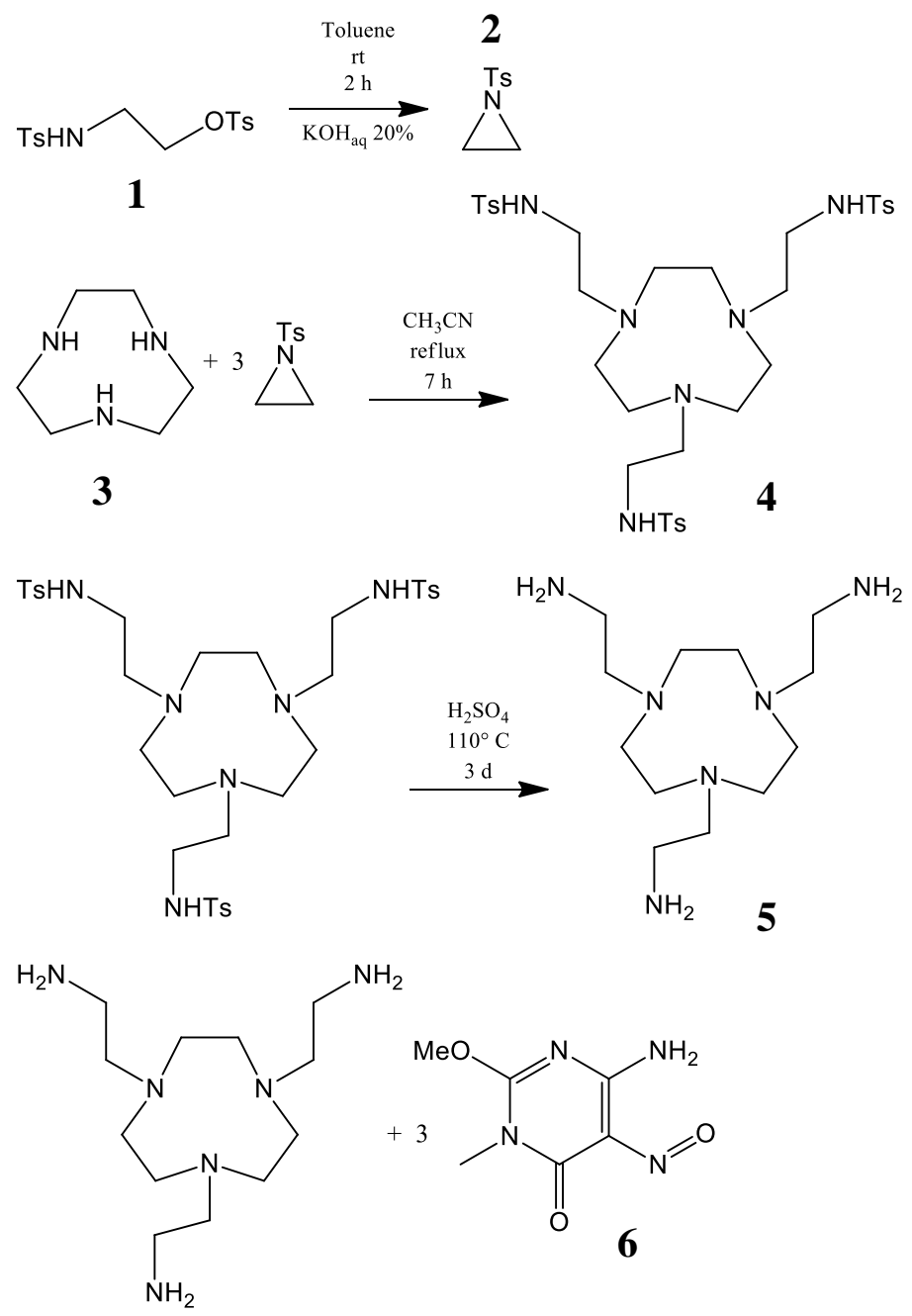<smiles>CO[C@H](C)CCNc1nc(N)c(N=O)c(=O)n1CCNc1nc(N)c(N=O)c(=O)n1C</smiles>

Scheme 1. Synthesis of $\mathbf{H}_{3} \mathbf{L}$.

\subsection{Potentiometric Measurements}

Ligand protonation constants were determined through potentiometric ( $\mathrm{pH}$-metric) titrations. The experiments were performed in $0.1 \mathrm{M} \mathrm{NaCl}$ at $298.1 \pm 0.1 \mathrm{~K}$ using previously described procedures and instrumentation $[40,41]$. Emf data acquisition was performed with the software PASAT $[42,43]$. The Metrohm 6.0262.100 combined electrode was calibrated as a $\mathrm{H}^{+}$concentration probe by titration of previously standardized amounts of $\mathrm{HCl}$ with $\mathrm{CO}_{2}$-free $\mathrm{NaOH}$ solutions. The determination of the equivalent point was performed by Gran's method [44], thus obtaining standard potential, $\mathrm{E}^{\circ}$, and ionic product of water $\left(\mathrm{pK}_{\mathrm{w}}=13.78(1)\right.$ in $0.1 \mathrm{M} \mathrm{NaCl}$ at $\left.298.1 \mathrm{~K}\right)$. The software HYPERQUAD [45] was employed in order to calculate the stability constants from emf data. Ligand concentration was about $1 \times 10^{-3} \mathrm{M}$ in all experiments. The studied $\mathrm{pH}$ range was 2.0-11. At least three measurements were performed for $\mathrm{H}_{3} \mathrm{~L}$ protonation constants determination. 


\subsection{Spectroscopic Measurements}

The ${ }^{1} \mathrm{H}$ NMR spectra were recorded in $\mathrm{D}_{2} \mathrm{O}$ at $25^{\circ} \mathrm{C}$ on a Bruker AV300 spectrometer (Bruker Italia, Milano, Italy). Absorption spectra were recorded at $298 \mathrm{~K}$ on a Jasco V-670 spectrophotometer (Jasco Europe, Cremella, LC, Italy). Ligand concentration for UV-Vis spectra was $1.2 \times 10^{-5} \mathrm{M}$. In the case of $\mathrm{Pd}(\mathrm{II})$ complexes, batchwise UV titration is conducted, as reaching equilibrium can require up to several (3-4) days. X-ray photoelectron spectroscopy (XPS) spectra were recorded while using $\mathrm{Al} \mathrm{K \alpha}$ radiation and a pass energy of $44 \mathrm{eV}$ using previously reported instrumentation and methods [46-48], namely using a model TA10 X-ray source and a model HA100 hemispherical analyzer (VSW Scientific Instrument Limited, Manchester, UK) with a 12 channels detector. The $\mathrm{C} 1 \mathrm{~s}$ transition at $284.8 \mathrm{eV}$ was used as a reference for obtaining the heteroatoms binding energies. It was not possible to carry out catalyst dismounting from the electrochemical cell and introduction in the XPS chamber maintaining the sample excluded from air.

\subsection{Preparation of $M W C N T s / H_{3} L$ and $M W C N T S / H_{3} L-P d(I I)$ Catalysts}

The preparation of said materials has been performed according to reported procedures [24-30,34]. In brief, MWCNTs (graphitized, $99.9 \%$ C, outer diameter 8-15 nm, inner diameter 3-5 nm, specific surface area $117 \mathrm{~m}^{2} / \mathrm{g}$, NanoAmor, TX, USA) were put in contact with a $1.0 \mathrm{mM}$ aqueous solution of the ligand maintaining a $1 \mathrm{mg}$ MWCNT/1 mL of solution ratio and gently shaken during three days. This is merely a precautionary timeframe, as the adsorption of polyamines functionalized with the same pyrimidine on MWCNTs happens via a Langmuir-type adsorption in a few $(2-3) \mathrm{h}[24,27,28,31,34]$. The $\mathrm{pH}$ of the solution was conveniently adjusted to 6 (in the $5-8 \mathrm{pH}$ range a single species exists, $\mathrm{H}_{4} \mathrm{~L}^{+}$, cf. Figure S1). After the said time, solid was recovered and amount of adsorbed ligand quantified by measuring residual ligand in solution (exploiting the $300 \mathrm{~nm}$ isosbestic point characteristic of this pyrimidine chromophore). MWCNTs $/ \mathrm{H}_{3} \mathrm{~L}$ was recovered as a solid product by filtration, briefly washed with milliQ water, and then dried in vacuum at r.t. to constant weight. Normally, imperfect adsorption (e.g., on edges or defect sites rather than on MWCNT surface) of similar ligands implies that a certain $\%$ of the adsorbed ligands (5-8\%, generally) can be displaced; therefore, desorption of the obtained MWCNT/ $\mathrm{H}_{3} \mathrm{~L}$ material was performed. MWCNT/ $\mathrm{H}_{3} \mathrm{~L}$ material was placed in contact again with milli-Q water at $\mathrm{pH} 6$ with a $1 \mathrm{mg} / 1 \mathrm{~mL}$ solid to solution ratio. After three days at r.t. under gentle shaking, the amount of desorbed ligand was quantified again, the solid recovered by filtration and dried. Desorption was repeated further on a portion of the material showing no further ligand desorption. The final amount of ligand adsorbed was $0.360 \mathrm{mmol} \mathrm{H}_{3} \mathrm{~L} / \mathrm{g}$ MWCNT.

The metal decoration of MWCNTs/ $\mathrm{H}_{3} \mathrm{~L}$ can also be easily achieved from aqueous solution. Accordingly, a weighted amount of MWCNTs $/ \mathrm{H}_{3} \mathrm{~L}$ was suspended in a solution containing one equivalent of $\mathrm{K}_{2} \mathrm{PdCl}_{4}$ at $\mathrm{pH} 5$ for six days. Given the high thermodynamic stability of $\mathrm{Pd}(\mathrm{II})$ complexes (simple ethylenediamine already affords complexation constants $>10^{20}$, i.e., free energy change of the complexation reaction exceeds $-115 \mathrm{~kJ} / \mathrm{mol}$ [49]) all $\mathrm{Pd}(\mathrm{II})$ was sequestered. Despite this expected behavior, Vis spectra were still checked for $\mathrm{PdCl}_{4}{ }^{2-}$ bands, which were not present anymore after metal coordination. The resulting material contains $0.272 \mathrm{mmol}$ of $\mathrm{Pd} / \mathrm{g}$, i.e., it has a $\mathrm{Pd}$ content $\mathrm{fo} 2.90 \%$ by weight.

\subsection{Preparation of the Modified Electrodes}

Immobilization of the catalysts onto a rotating glassy carbon (GC) working electrode was achieved by preparing an ink consisting of MWCNT/ $\mathrm{H}_{3} \mathrm{~L}-\mathrm{Pd}(\mathrm{II})$ dispersed in a polymeric membrane (Nafion), which was then cast on the GC disk. The samples were prepared according to reported procedures [24]. In brief, composition of wet ink is as follows: catalyst $2 \%$, water $52 \%, \mathrm{EtOH} 26 \%$, Nafion ${ }^{\circledR}$ ion exchange resin $20 \%$. 


\subsection{Electrochemical Characterization}

The rotating ring disk electrode (RRDE) experiments were performed using a Pyrex ${ }^{\mathrm{tm}}$ (Princeton Applied Research, Oak Ridge, TN, USA) glass cell that was filled with $0.1 \mathrm{M} \mathrm{KOH}$ solution. The reference electrode was a commercial (Princeton Applied Research) Ag/AgCl/sat. KCl with a potential of $+197 \mathrm{mV}$ with respect to the normal hydrogen electrode (NHE). A platinum gauze enclosed in a glass tube with porous bottom constitutes the counter electrode. A model 636A rotating ring-disk electrode and a PGSTAT 100N bi-potentiostat were employed. A Pine ${ }^{\mathrm{tm}}$ (Durham, NC, USA) ring-disk electrode (E6 Series), with platinum ring electrode and GC disk electrode covered with the catalyst layer (see above), was the working electrode. The size of electrodes: GC disk insert, $\varnothing 5 \mathrm{~mm}\left(\mathrm{~A}=0.196 \mathrm{~cm}^{2}\right)$; Pt ring $\left(A=0.11 \mathrm{~cm}^{2}\right)$. Ring and disk currents were recorded simultaneously. $\mathrm{K}_{3} \mathrm{Fe}(\mathrm{CN})_{6}$ calibration in $\mathrm{N}_{2}$-saturated $\mathrm{KOH} 0.1 \mathrm{M}$ was employed in order to determine the collection $\mathrm{HO}_{2}{ }^{-}$efficiency ( $\left.\mathrm{N}=\mathrm{I}_{\text {ring }} / \mathrm{I}_{\text {disk }}\right)$ of the ring-disk electrode. The fractional yields of $\mathrm{HO}_{2}{ }^{-}$in the ORR were calculated from the RRDE currents as $\mathrm{X}\left(\mathrm{HO}_{2}{ }^{-}\right)=\left(2 \mathrm{I}_{\text {ring }} / \mathrm{N}\right) /\left(\mathrm{I}_{\text {disk }}+\mathrm{I}_{\text {ring }} / \mathrm{N}\right)$. RRDE measurements were carried out at a scan rate of $5 \mathrm{mVs}^{-1}$ with a $1600 \mathrm{rpm}$ rotation rate, while the Pt ring electrode was held at $+0.50 \mathrm{~V}$ versus $\mathrm{Ag} / \mathrm{AgCl} / \mathrm{sat}$. $\mathrm{KCl} . \mathrm{N}_{2}$, or $\mathrm{O}_{2}$ were used to purge the solution to achieve oxygen-free or oxygen-saturated electrolyte solution. Still, $\mathrm{CVs}$ in $\mathrm{N}_{2}$ and $\mathrm{O}_{2}$ are reported in the Supplementary Material (Figure S2).

For the optimal catalyst loading, sample 3, the number of exchanged electrons was also evaluated by working in RDE (rotating disk electrode) mode at a different scan speed and using the Koutechy-Levich (KL) equation. The general procedure has already been described elsewhere [18].

All of the onset potentials $\left(E_{o n}\right)$ reported are quantified with a general methodology that we previously reported [24]; one example is given in the Supplementary Material (Figure S3).

\subsection{Scanning Transmission Electron Microscopy (STEM) Characterization}

Electron microscopy characterization was done using a state of the art 200kV STEM microscope (JEOL, Tokyo, Japan, Model 2200FS) that was equipped with a probe and image aberration correctors (CEOS, Heidelberg, Germany). HAADF (high angle annular dark field) STEM images were acquired while using an 80 mrad inner collection semi-angle and an outer collection semi-angle of $180 \mathrm{mrad}$. The samples for STEM analysis were prepared by finely crushing grains of MWCNT powder between glass slides and tapping holey carbon films supported by standard Cu TEM grids directly on to the thinner areas of the crushed powders. TEM grids were thermally pre-treated following the procedure that is described in ref [50]. Excess powder was then removed by flicking the grids onto the edges of the glass slides under a fume hood before transfer to single tilt TEM sample holders. The sample was kept in the TEM holder in a vacuum rig overnight before measurements to reduce moisture at $5 \times 10^{-7}$ mbar vacuum pressure.

\section{Results and Discussion}

\subsection{Ligand Protonation Equilibria}

Table 1 lists equilibrium constants that were determined for ligand protonation by means of potentiometric (pH-metric) titrations (aqueous solution; $0.1 \mathrm{M} \mathrm{NaCl} ; 298.1 \mathrm{~K} ; \mathrm{pH}$ range 2.0-11).

Table 1. Protonation constants of $\mathrm{H}_{3} \mathrm{~L}$ (aqueous solution; $0.1 \mathrm{M} \mathrm{NaCl} ; 298.1 \pm 0.1 \mathrm{~K}$ ). Values in parentheses are standard deviations on the last significant figures.

\begin{tabular}{cc}
\hline Equilibrium & $\log \mathrm{K}$ \\
\hline $\mathrm{HL}^{2-}+2 \mathrm{H}^{+}=\mathrm{H}_{3} \mathrm{~L}$ & $21.65(1)$ \\
\hline $\mathrm{H}_{3} \mathrm{~L}+\mathrm{H}^{+}=\mathrm{H}_{4} \mathrm{~L}^{+}$ & $9.84(1)$ \\
\hline $\mathrm{H}_{4} \mathrm{~L}^{+}+\mathrm{H}^{+}=\mathrm{H}_{5} \mathrm{~L}^{2+}$ & $3.42(3)$ \\
\hline $\mathrm{H}_{5} \mathrm{~L}^{2+}+\mathrm{H}^{+}=\mathrm{H}_{6} \mathrm{~L}^{3+}$ & $2.45(3)$ \\
\hline $\mathrm{H}_{6} \mathrm{~L}^{3+}+2 \mathrm{H}^{+}=\mathrm{H}_{8} \mathrm{~L}^{5+}$ & $4.54(4)$ \\
\hline
\end{tabular}


The species distribution diagram as a function of $\mathrm{pH}$ is reported as Supplementary Materials (Figure $\mathrm{S} 1$ ). In the studied $\mathrm{pH}$ range, $\mathrm{H}_{3} \mathrm{~L}$ behaves as an heptaprotic molecule. In agreement with the behavior of analogous polyamines functionalized with the same pyrimidine derivative [27-36], the secondary amines directly connected to the pyrimidine residues can be deprotonated at $\mathrm{pH} \approx 11$, while the pyrimidine nitroso groups are protonated below $\mathrm{pH} 2.5$. These protonation equilibria are generally easily followed through UV-Vis measurements, as they significantly alter $\pi-\pi^{*}$ transitions of the chromophore. The characteristic absorption wavelengths have been commented elsewhere $[27,28,31,34,36,51,52]$, and they are only affected slightly by the nature of appended polyamine. Uv-Vis spectra of the ligand at different pHs, as reported in Figure 2, clearly show three absorption bands at 328, 271, and $230 \mathrm{~nm}$. Combining potentiometric and spectroscopic measurements by superimposing species distribution diagram (derived from potentiometric data) and UV bands trends with $\mathrm{pH}$ (Figure 3), it is possible to rationalize the ligand protonation. This allows for understanding which of the observed protonation processes affect the chromophores, altering UV bands, and which the spectrophotometrically silent macrocycle. The most deprotonated species in solution is $\mathrm{HL}^{2-}$. The complete deprotonation to $\mathrm{L}^{3-}$ is not achieved in the $2.0-11.0 \mathrm{pH}$ range of potentiometric measurements (extending $\mathrm{pH}$ range would offer no benefit due to large alkaline errors in a $\mathrm{Na}^{+}$medium). However, UV spectra confirm that, between $\mathrm{pH} 11$ and 12 , spectral changes are still observed, suggesting a $\log K>11.5$ for $\mathrm{L}^{3-}$ protonation. The first observed two proton equilibrium $(\log K=21.65)$ mainly involve the remaining equivalent anionic $\mathrm{N}$-pyr sites, as demonstrated by important changes in the UV spectra. The entrance of the fourth proton has no further effect on UV-Vis bands, as it involves the macrocycle ( $\log K=9.84$, i.e., still a base of remarkable strength). $\mathrm{H}_{4} \mathrm{~L}^{+}$is the most persistent form of the ligand in solution, dominating the distribution diagram for at least four $\mathrm{pH}$ units: this is convenient for achieving MWCNT functionalization with a single species/protonation state. Formation of $\mathrm{H}_{5} \mathrm{~L}^{2+}(\log K=3.42)$ does not alter spectroscopic properties either, as the fifth proton is still localized onto the macrocycle. Starting from $\mathrm{H}_{6} \mathrm{~L}^{3+}(\log \mathrm{K}=2.45)$ absorption spectra are again affected, signaling that protonation happens on pyr-NO groups. The further addition of two protons to give $\mathrm{H}_{8} \mathrm{~L}^{5+}\left(\log \mathrm{K}=4.54\right.$ for $\left.2 \mathrm{H}^{+}\right)$has a profound effect on absorption spectra, as it happens on equivalent pyr-NO groups. The eventual last protonation of the macrocycle is not observed, as it most likely only happens in extremely acidic $\mathrm{pH}$ ranges. In the end, of the nine expected acid-base equilibria, seven can be fully characterized and 2 lay beyond the extremes of explored $\mathrm{pH}$ range, although all of them are fully rationalized, owing to associated spectral variations. The characteristic isosbestic point at around $300 \mathrm{~nm}$ is also particularly convenient for ligand quantification in solution.
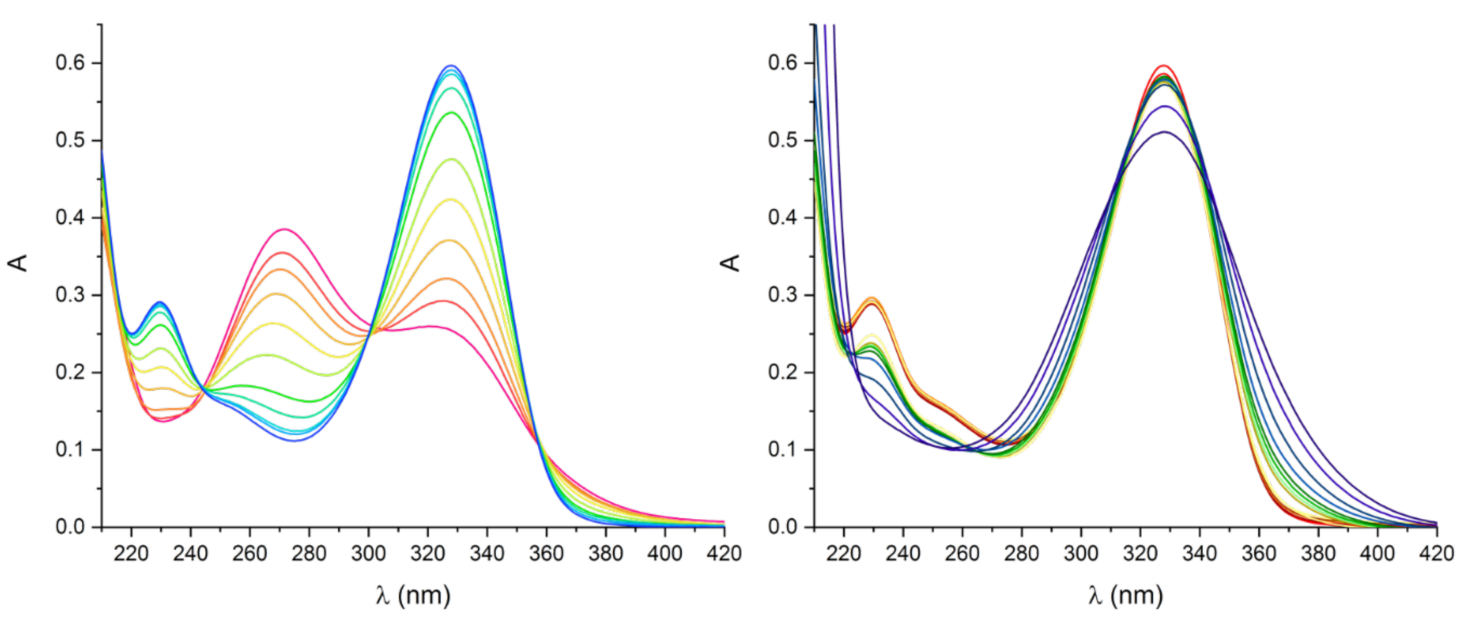

Figure 2. Acidic (left) (pink pH 0.83 to blue $\mathrm{pH} 4.2$ ) and alkaline (right) (pink pH 4.2 to violet $\mathrm{pH} 12.3$, first differing spectrum $\mathrm{pH}$ 9.1) branches of $\mathrm{H}_{3} \mathrm{~L}$ UV-Vis absorption spectra $\left(\left[\mathrm{H}_{3} \mathrm{~L}\right]=1.2 \times 10^{-5} \mathrm{M}\right)$. 


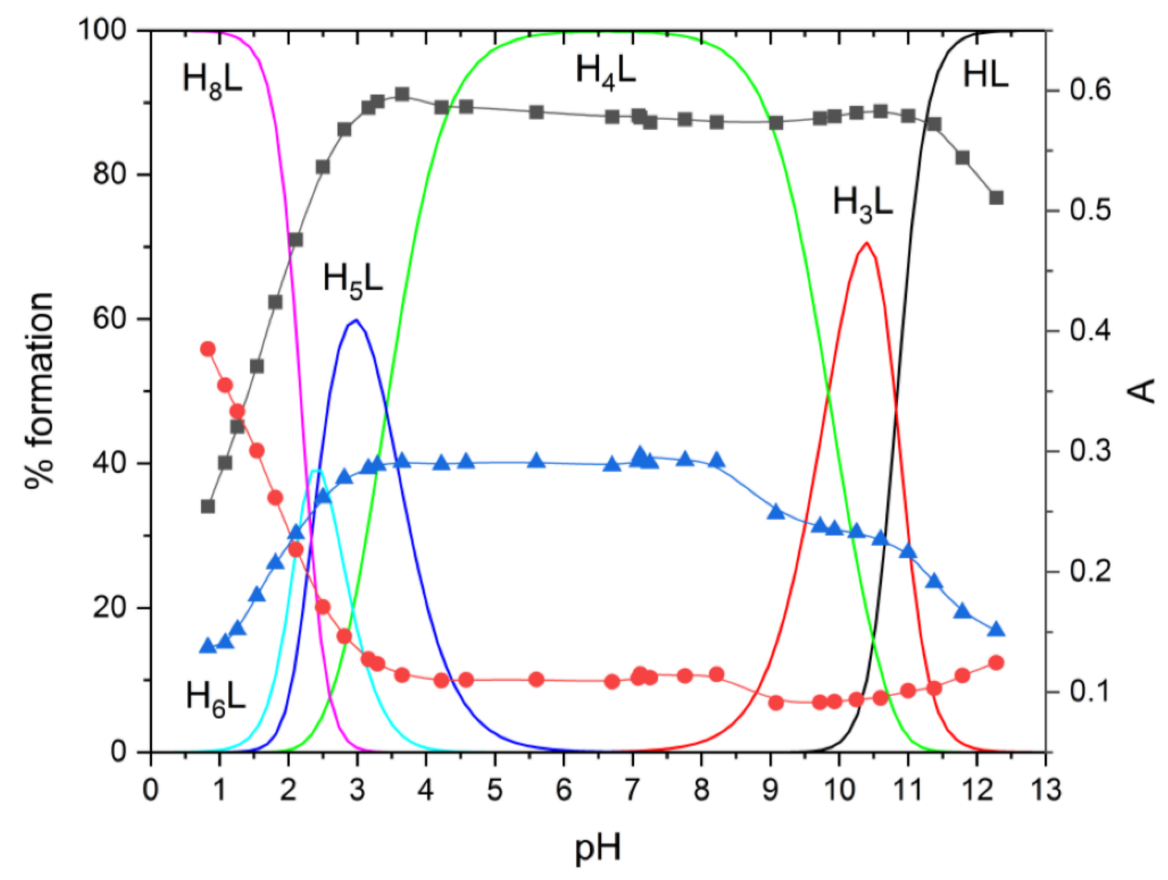

Figure 3. pH dependence of 328 (black), 271 (red), and 230 (blue) nm absorption bands superimposed to species distribution diagram $\left(\left[\mathrm{H}_{3} \mathrm{~L}\right]=1.2 \times 10^{-5} \mathrm{M}\right)$. Charges omitted for simplicity.

\subsection{Pd(II) Complexes Formation}

As mentioned in the experimental section, $\mathrm{Pd}(\mathrm{II})$ complexes of simple polyamines generally possess high thermodynamic stability [49]. The firm complexation of the metal cation is self-evident, as chelating and macrocyclic ligands afford further stabilization of such complexes. This being said, as determination of very large stability constants present inherent difficulties, which are further aggravated by $\mathrm{Pd}(\mathrm{II})$ kinetic inertness, the identification of all complex species formed by this metal ion under different $\mathrm{pH}$ conditions and the determination of the corresponding stability constants are generally impossible.

Nevertheless, batch spectrophotometric $\mathrm{pH}$ titration of a 1:1 $\mathrm{Pd}(\mathrm{II}): \mathrm{H}_{3} \mathrm{~L} 1.2 \times 10^{-5}$ solution and comparison of molar attenuation coefficient with respect to $\mathrm{H}_{3} \mathrm{~L}$ alone (Figure 4) reveals complex formation. It appears that the $\mathrm{Pd}$ (II) complex is already formed in very acidic medium, in accordance with the high stability of the complex and, hence, of the ineffective proton competition, even at low $\mathrm{pH}$, and it remains stable all the way to alkaline conditions, again in accordance with expected stability. As the ligand never regains its free spectrum, the complex appears to be resistant towards demetallation over the explored $\mathrm{pH}$ range. Full spectra are available in supporting material, as in Figure S4. This information, as for other related ligands [24], is useful as preliminary assessment to check that the complex can sustain (as found, cf. Sections 3.3 and 3.4) pH conditions that are relevant to ORR experiments. 


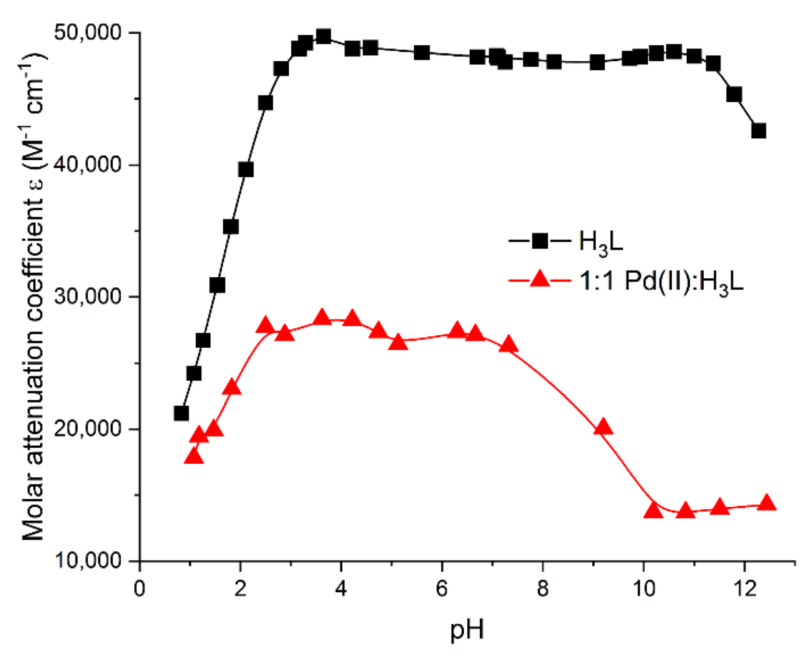

Figure 4. Measured molar attenuation coefficient of the $328 \mathrm{~nm}$ band of $\mathrm{H}_{3} \mathrm{~L}$ alone (black) or in the presence of 1 eq of $\mathrm{Pd}(\mathrm{II})$ (red). Complex formation is observed in the whole explored $\mathrm{pH}$ range.

\subsection{Electrochemical Evaluation of Catalytic Performance}

The results of the electrochemical studies are summarized in Table 2 and Figure 5.

Table 2. Catalytic performances of our catalyst.

\begin{tabular}{|c|c|c|c|c|c|c|}
\hline Sample & Ink Loading (mg) & $\mathrm{n}_{\text {theo }}(-0.5 \mathrm{~V})^{\mathrm{a}}$ & $\mathrm{n}_{\exp }(-0.5 \mathrm{~V})^{\mathrm{b}}$ & $\mathrm{N}_{\exp }{ }^{\mathrm{c}}$ & $E_{\text {on }}(V)^{d}$ & $E_{1 / 2}(V)^{e}$ \\
\hline 1 & 2.4 & 4.00 & 4.00 & 0.229 & -0.0670 & -0.19 \\
\hline 2 & 3.3 & 3.55 & 3.93 & 0.200 & -0.0288 & -0.11 \\
\hline 3 & 8.7 & 3.68 & 3.96 & 0.233 & -0.0066 & -0.11 \\
\hline 4 & 12.5 & 3.69 & 3.88 & 0.197 & -0.0605 & -0.15 \\
\hline
\end{tabular}

Increasing quantities of ink were initially deposited on the GC electrode and tested in order to screen for optimal electrode preparation in terms of catalyst loading. Although the deposition of small ink amount $(2.4 \mathrm{mg}, 1)$ was already sufficient for appreciating the catalytic effect, if was found that the deposition of an increased amount of catalyst would translate into superior catalytic performances, with optimum response at about four times the initial amount $(8.7 \mathrm{mg}, 3)$. The deposition of larger ink quantities resulted instead in being detrimental. This could be due to a non-significant increase of catalytic sites, which might remain non-accessible to gases, accompanied by a change of the texture of the electrode, potentially causing diffusion issues.

In the abovementioned optimal conditions, sample 3, the system is observed to display promising catalytic activity in the half cell studies, featuring an $E_{\text {on }}$ of only $-0.0067 \mathrm{~V}$ with respect to reference electrode and a number of exchanged electrons $(n)$ close to four (3.96), i.e., promoting almost selectively direct water formation.

Calibration with $\mathrm{K}_{3} \mathrm{Fe}(\mathrm{CN})_{6}$ has been used to determine the experimental collection efficiency number in each case, so that accurate values for number of exchanged electrons could be derived. 


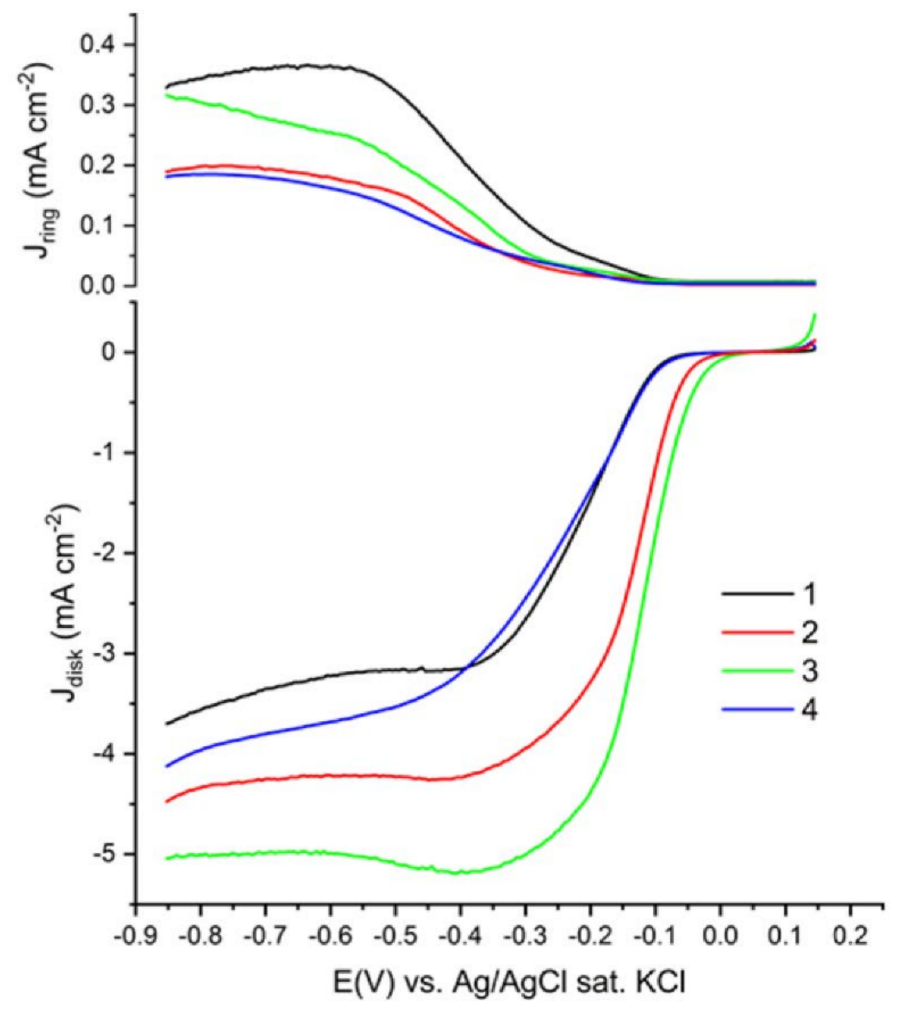

Figure 5. Rotating ring disk electrode (RRDE) ring (top) and disk (bottom) currents showing ORR activities of the investigated samples. Sample numbers 1-4 refer to Table 2. Rotation rate: $1600 \mathrm{rpm}$. Scan rate: $5 \mathrm{mV} / \mathrm{s}$.

We deemed it important to further verify the number of exchanged electrons, especially for sample 3, with an independent method, i.e., RDE experiments and Koutechy-Levich (KL) equation. Such a treatment allows for an independent indirect determination of $\mathrm{n}$. To do so, LSVs at different spin rates have been performed (Figure 6), and meaningful information extracted from the double reciprocal $\mathrm{J}_{\text {disk }}{ }^{-1}$ vs. $\omega \frac{1}{2}$ plot (with $\omega$ spin rate expressed in rad s ${ }^{-1}$ ) by linear regression (Figure S5) (cf. Materials and Methods section). This is important in a preliminary study, such as ours, since the generation and accumulation of peroxide, via a concurrent $2 \mathrm{e}^{-}$process, can be detrimental to the long-term viability of the catalyst. It was found that KL treatment affords, in this case, a very similar result ( $n=3.92, \mathrm{R}^{2}$ for KL fitting 0.999 ) with respect to RRDE value (3.96).

In order to complete the half-cell characterization of the new catalyst, time viability has been probed. For this task the catalyst was left working for $1.5 \mathrm{~h}$ at $-0.4 \mathrm{~V} \mathrm{vs}$. $\mathrm{Ag} / \mathrm{AgCl} / \mathrm{sat} . \mathrm{KCl}$ (galvanostatic mode), with currents (and hence RRDE number of exchanged electrons) continuously monitored. This test showed no sign of drift of monitored parameters (Figure S6). 


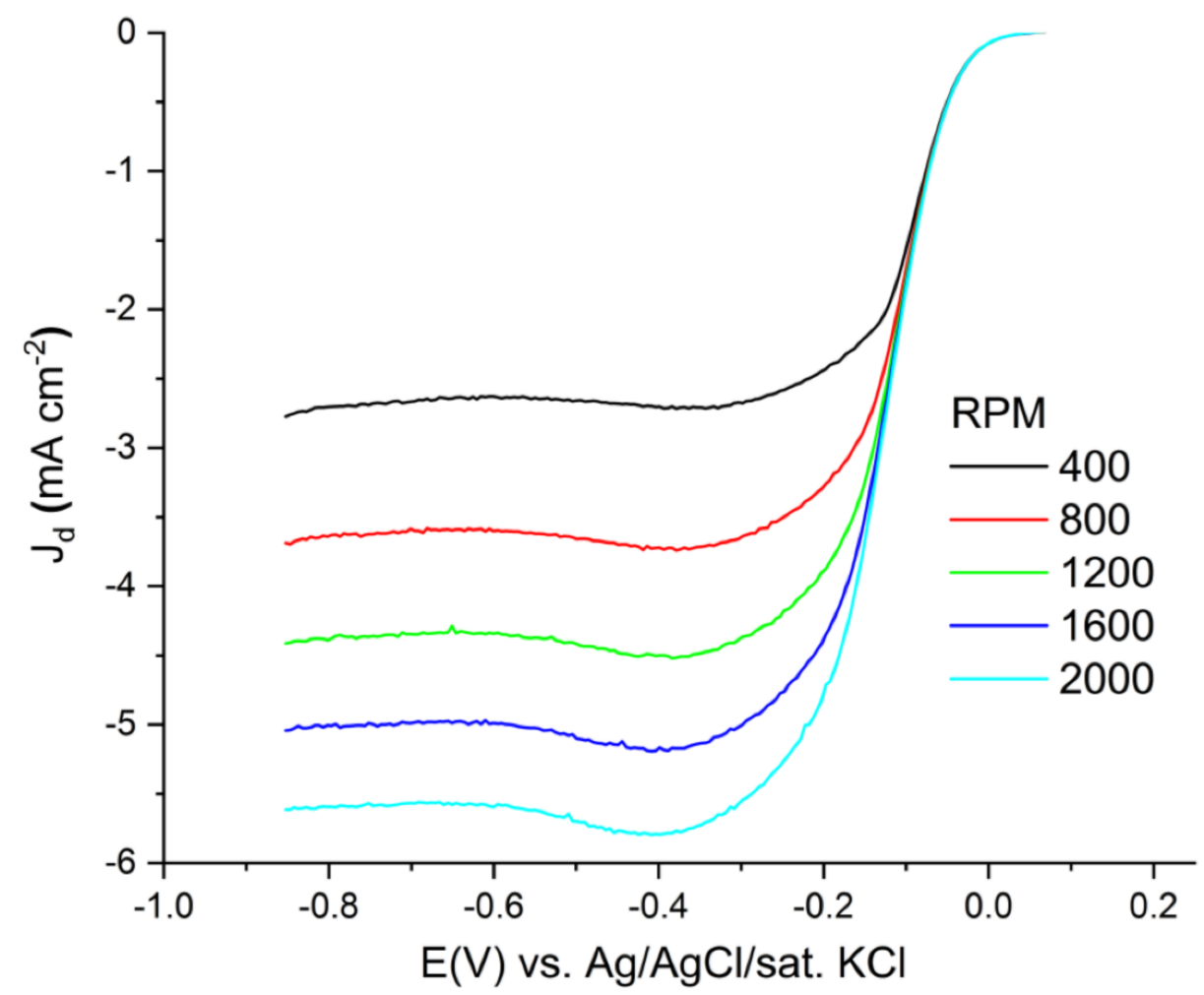

Figure 6. LSVs (linear sweep voltammograms) recorded at different spin rates (400; 800; 1200; 1600; $2000 \mathrm{rpm}$ ) at $20 \mathrm{mV} / \mathrm{s}$ scan rate of sample 3.

\subsection{Before and After-Use Analysis}

After the galvanostatic test, the catalyst was collected. XPS and STEM investigation were performed on the as-prepared and after-use catalysts.

XPS analysis mainly focused on the Pd region (Figure 7). This is the most diagnostic region for our system, potentially allowing to detect irreversible alterations due to the electrochemical treatment, the most common of which involve Pd oxidation state. In our conditions (alkaline media, reducing potential), both the replacement of $\mathrm{N}$ donor groups with $\mathrm{O}$ donors (i.e., transition from $\mathrm{Pd}(\mathrm{II})$ complexes to $\mathrm{PdO})$ as well as reduction to $\mathrm{Pd}(0)$ are possible outcomes. XPS spectra reveals that the main oxidation state of the metal is +2 and that it is mostly maintained even after use. The as prepared sample contains a small amount $(\approx 12 \%$, as evaluated from XPS spectra) of more reduced Pd, giving rise to the minor shoulder at $333.4 \mathrm{eV}$ (Figure S7). Similar behavior was showed by a graphene-supported $\mathrm{Pd}(\mathrm{II})$ complex prepared by the same route, and it is perhaps connected to preparation method and/or reducing character of leftover $\mathrm{C}$ impurities or Pd interactions with surface defects [28]. The main modifications that are introduced by the electrochemical treatment of the sample are the appearance of $348 \mathrm{eV}$ peak and the broadening of Pd main peak at $337.5 \mathrm{eV}$. The analysis of Pd peak reveals a growth of $\mathrm{Pd}$ reduced component (now about $40 \%$, Figure S7) with respect to $\mathrm{Pd}(\mathrm{II})$ main component and its shift towards typical $\mathrm{Pd}(0)$ values (observed $334.7 \mathrm{eV}$ ). The $348 \mathrm{eV}$ is most likely spurious, and it has been attributed to a Ca impurity (typical peak at $351.1 \mathrm{eV}$ is also observed). Ca is easily detected by XPS and little impurities might come from water samples and/or glassware (in consideration of the $0.1 \mathrm{M} \mathrm{KOH}$ environment). Both relative robustness of similar Pd(II) complexes towards redox processes [24] and cases featuring $\mathrm{Pd}(0)$ NPs growth [28] had previously been reported, depending on the nature of the ligand used and its ability to protect the metal's oxidation state. 


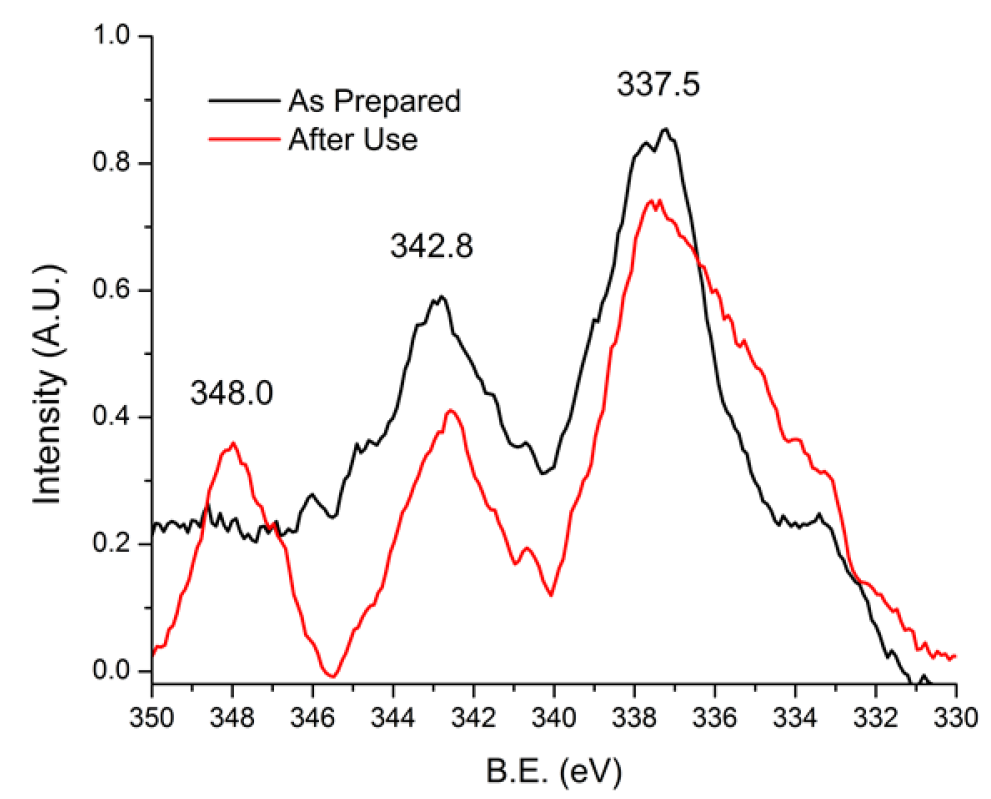

Figure 7. Before and after use $(1.5 \mathrm{~h}-0.4 \mathrm{~V}$ vs. $\mathrm{Ag} / \mathrm{AgCl} / \mathrm{sat} . \mathrm{KCl}) \mathrm{Pd} \mathrm{XPS}$ spectra of the catalyst.

As-prepared MWCNT/ $\mathrm{H}_{3} \mathrm{~L}-\mathrm{Pd}(\mathrm{II})$ can be seen in the STEM images shown in Figure 8. The MWCNTs are bundled together, forming grains of several micron size (Figure 8a). Images reveal the structure of the nanotubes and the distribution of the Pd. After deposition, the nanotubes maintain their crystallinity, as shown in the HR-bright field STEM images in Figure 8b-d. The typical contrast of graphitic planes of the nanotubes multi-walls is visible edge-on as well as the in plane in Figure 8d. HAADF STEM images, where the intensity is roughly proportional to the square of the atomic number of the elements in the field of view $\left(I \propto Z^{2}\right)$, are able to highlight the presence of heavy elements over the carbon material. Pd is well distributed on to the nanotubes surface. Some larger clusters, with particle size of 2-3 nanometers Figure $8 \mathrm{c}-\mathrm{e}$ ), are distributed on the sample. In addition, in-between them, a finer dispersion of smaller Pd-based clusters of sub-nanometer size can be appreciated, as indicated by the white arrows in Figure 8e). 


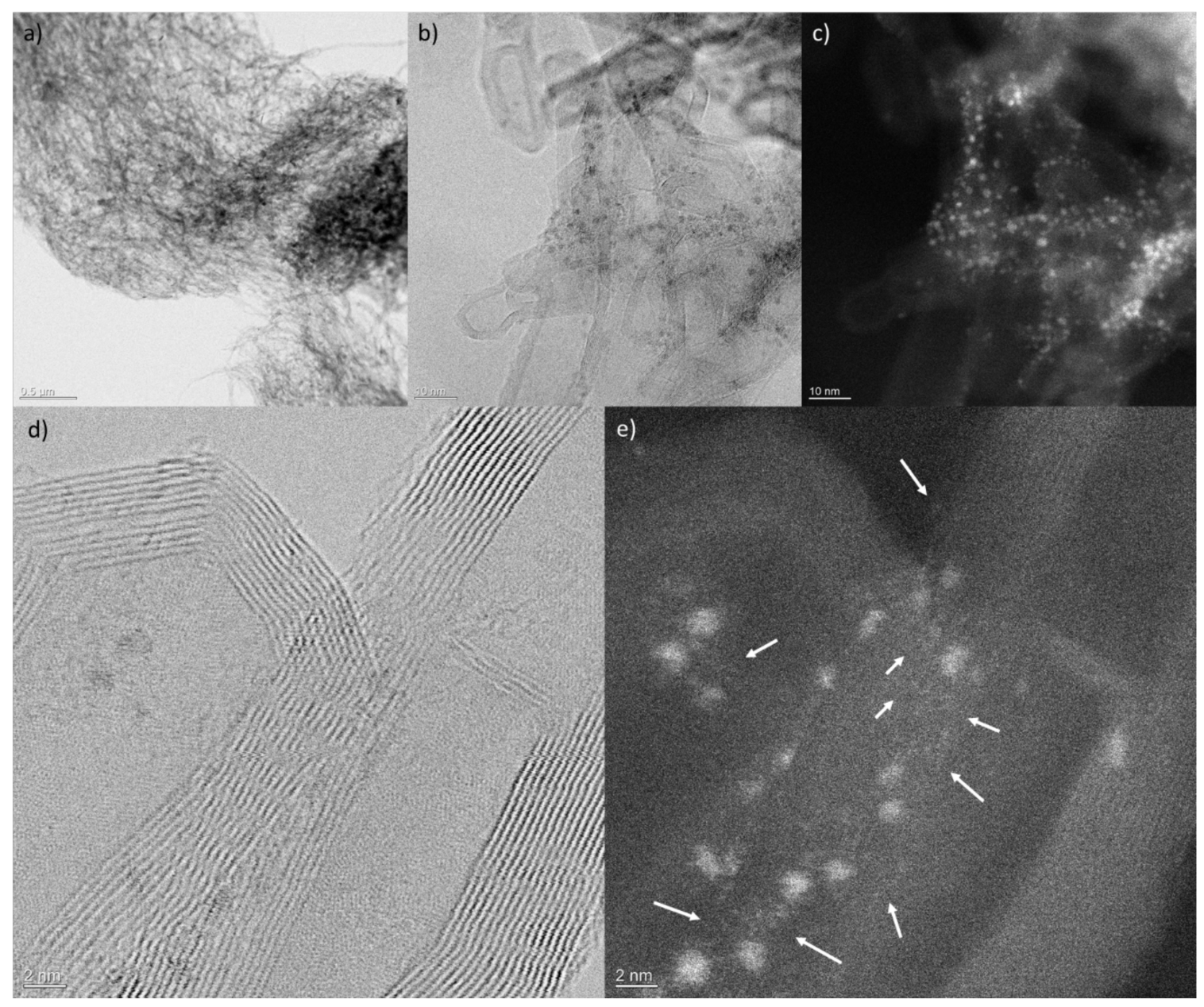

Figure 8. Scanning Transmission Electron Microscopy (STEM) images of as deposited sample. (a) Overview BF image showing a bundle of multi-walled carbon nanotubes (MWCNTs); (b) higher magnification BF stem image showing the MWCNTs and the Pd as dark patches. (c) High Angle Annular Dark Field (HAADF) Stem images showing Pd distribution as 2-3 nm clusters. (d) HR-BF STEM image showing MWCNTs crystallinity, and (e) HR-HAADF showing 2-3 nm and sub-nanometer clusters of Pd (indicated by white arrows).

After use, the sample has a more compact structure, with MWCNTs embedded in amorphous material (See Figure 9a). Although the resolution is reduced by the presence of the amorphous material and its overall thickness, graphitic planes of the nanotubes walls are still clearly visible on the edges of the grains (Figure 9b). The brighter contrast in the HAADF STEM image in Figure 9c shows a Pd rearrangement on the surface, forming a network-like structure rather that single clusters. It could be concluded, given the limited impact that this rearrangement has on electrochemical performance, that the obtained Pd nanostructured network, as stabilized by the ligand, still allows a superior accessibility of the active sites. 

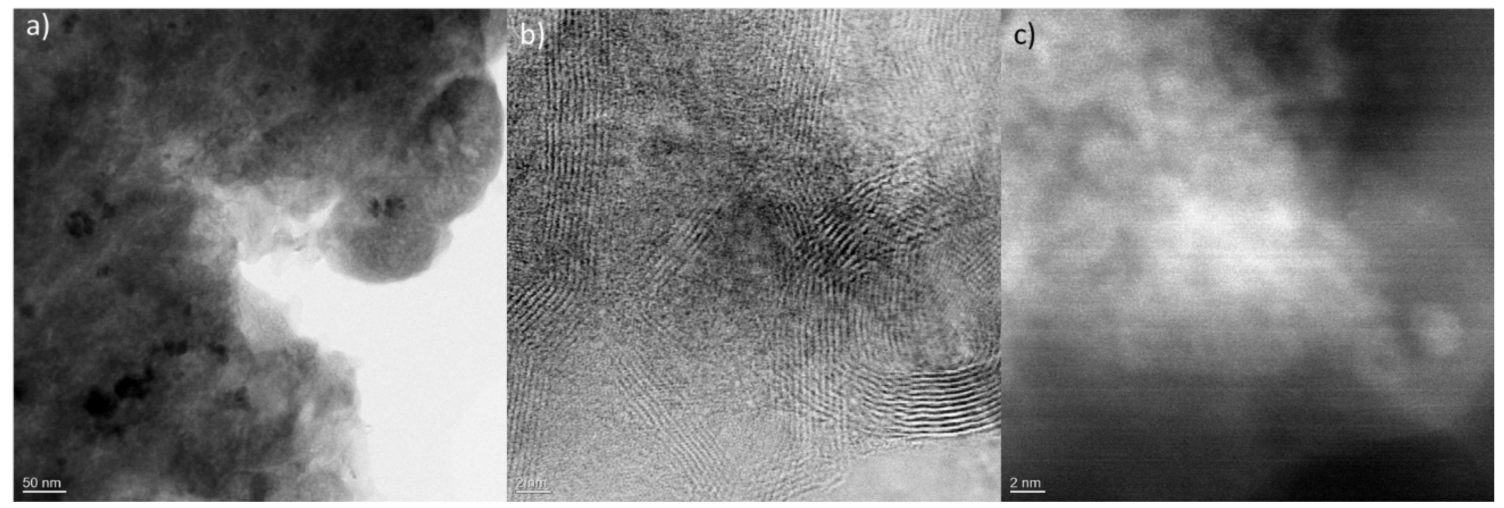

Figure 9. STEM images of sample after use. (a) Overview BF image showing a more compact structure of MWCNT; (b) HR-BF STEM image showing MWCNTs imbedded into amorphous material. (c) HAADF STEM image of the same area, as in (a), Pd redistributed in a network-like structure.

\section{Conclusions}

Our approach to graphitic surface decoration afforded supported Pd(II) complexes with overall low $(2.90 \% w / w)$ Pd content. The obtained catalyst displays considerable catalytic activity ( $\mathrm{E}_{\text {on }}$ up to $-0.0066 \mathrm{~V}$ vs. $\mathrm{Ag} / \mathrm{AgCl} / \mathrm{sat} . \mathrm{KCl})$ and an almost exclusive $(\approx 98 \%) 4 \mathrm{e}^{-}$process. These results, especially $E_{\text {on }}$ values, surpass those that we already reported for MWCNT/HL2-Pd(II) [24] (Sample $3 E_{\text {on }}-0.0066$ $\mathrm{V}$ vs. MWCNT/HL2-Pd(II) $\mathrm{E}_{\text {on }}-0.014 \mathrm{~V}$ [24], both vs. $\mathrm{Ag} / \mathrm{AgCl} / \mathrm{sat}$. $\mathrm{KCl}$ ), which, in turn, exceeded the performance of a solid commercial Pt polycrystalline electrode. STEM investigation shows textural modification after use, still the comparison of before and after use catalyst (STEM, XPS, electrochemical) demonstrates the substantial preservation of catalytic performance. This can be already regarded as a success for an emerging strategy for catalyst preparation. In this sense, our green approach (water, r.t.) has been further improved by replacing custom polyazamacrocycles with commercial alternatives, cutting the catalyst cost. In terms of performance, the positive results of this preliminary half-cell study could support the catalyst as a good candidate for further investigation addressing its behaviour in a complete cell. Accessing true and stable SACs through a supramolecular route instead, while it is true that most $\mathrm{Pd}$ remained in its +2 state and its partial reduction to $\mathrm{Pd}(0)$ did not affect the catalytic study, still requires efforts in the ligand design stage in order to better prevent undesired reductive processes.

Supplementary Materials: The following are available online at http://www.mdpi.com/1996-1073/13/21/5539/s1, Figure S1. Species distribution diagram for the $\mathrm{H}_{3} \mathrm{~L}$ ligand; Figure S2: sample still CVs in $\mathrm{N}_{2} / \mathrm{O}_{2} ;$ Figure S3: graphical definition of $\mathrm{E}_{\text {on }}$ as employed in this study; Figure S4: H3L:Pd(II) 1:1 solution UV spectra.; Figure S5: KL regression plot; Figure S6 Time viability of the catalyst; Figure S7: XPS analysis showing different Pd peaks analysis.

Author Contributions: Conceptualization, M.S., A.B. and M.I.; methodology, M.S., M.P., L.L.; validation, M.P., W.G., L.L.; formal analysis, M.S., M.P., L.L.; investigation, M.S., M.P., W.G., L.L.; resources, L.L., A.B., M.I.; data curation, M.S., M.P.; writing—original draft preparation, M.S.; writing-review and editing, all authors; visualization, M.S., M.P., L.L.; supervision, A.B., M.I.; project administration, A.B., M.I.; funding acquisition, A.B., M.I. All authors have read and agreed to the published version of the manuscript.

Funding: This research received no external funding.

Acknowledgments: L.L. would like to acknowledge financial support from the University of York Research Theme Champions' Travel and Networking Fund.

Conflicts of Interest: The authors declare no conflict of interest. 


\section{Abbreviations: List of Used Abbreviations (Alphabetical Order)}

$\begin{array}{ll}\text { CV } & \text { Cyclic Voltammogram } \\ \mathrm{E}_{1 / 2} & \text { Half-Wave Potential } \\ \mathrm{E}_{\mathrm{On}} & \text { Onset Potential } \\ \mathrm{GC} & \text { Glassy Carbon } \\ \text { HAADF } & \text { High Angle Annular Dark Field } \\ \text { KL } & \text { Koutechy-Levich } \\ \text { LSV } & \text { Linear Sweep Voltammogram } \\ \text { MWCNTs } & \text { Multi-Walled Carbon Nanotubes } \\ \mathrm{N} & \text { Collection Efficiency Number } \\ n & \text { Number of Exchanged Electrons } \\ \text { ORR } & \text { Oxygen Reduction Reaction } \\ \text { PGM } & \text { Platinum Group Metals } \\ \text { RDE } & \text { Rotating Disk Electrode } \\ \text { RRDE } & \text { Rotating Ring Disk Electrode } \\ \text { SAC } & \text { Single Atom Catalyst } \\ \text { STEM } & \text { Scanning Transmission Electron Microscopy } \\ \text { XPS } & \text { X-ray Photoelectron Spectroscopy }\end{array}$

\section{References}

1. Shindell, D.; Smith, C.J. Climate and air-quality benefits of a realistic phase-out of fossil fuels. Nature 2019, 573, 408-411. [CrossRef] [PubMed]

2. Air Quality in Europe 2019—European Environment Agency. Available online: https://www.eea.europa.eu/ publications/air-quality-in-europe-2019 (accessed on 6 July 2020).

3. Mahato, S.; Pal, S.; Ghosh, K.G. Effect of lockdown amid COVID-19 pandemic on air quality of the megacity Delhi, India. Sci. Total Environ. 2020, 730, 139086. [CrossRef] [PubMed]

4. Ball, M.; Basile, A.; Veziroğlu, T.N. (Eds.) Compendium of Hydrogen Energy; Woodhead Publishing Series in Energy; Woodhead Publishing: Oxford, UK, 2016; ISBN 978-1-78242-364-5.

5. Hoogers, G. Fuel Cell Technology Handbook; CRC Press: Boca Raton, FL, USA, 2002; ISBN 978-1-4200-4155-2.

6. Brockway, P.E.; Owen, A.; Brand-Correa, L.I.; Hardt, L. Estimation of global final-stage energy-return-oninvestment for fossil fuels with comparison to renewable energy sources. Nat. Energy 2019, 4, 612-621. [CrossRef]

7. Kulkarni, A.; Siahrostami, S.; Patel, A.; Nørskov, J.K. Understanding Catalytic Activity Trends in the Oxygen Reduction Reaction. Chem. Rev. 2018, 118, 2302-2312. [CrossRef]

8. Stacy, J.; Regmi, Y.N.; Leonard, B.; Fan, M. The recent progress and future of oxygen reduction reaction catalysis: A review. Renew. Sustain. Energy Rev. 2017, 69, 401-414. [CrossRef]

9. Shao, M.; Chang, Q.; Dodelet, J.-P.; Chenitz, R. Recent Advances in Electrocatalysts for Oxygen Reduction Reaction. Chem. Rev. 2016, 116, 3594-3657. [CrossRef]

10. Huang, X.; Wang, Y.; Li, W.; Hou, Y. Noble metal-free catalysts for oxygen reduction reaction. Sci. China Chem. 2017, 60, 1494-1507. [CrossRef]

11. Miller, H.A.; Bevilacqua, M.; Filippi, J.; Lavacchi, A.; Marchionni, A.; Marelli, M.; Moneti, S.; Oberhauser, W.; Vesselli, E.; Innocenti, M.; et al. Nanostructured Fe-Ag electrocatalysts for the oxygen reduction reaction in alkaline media. J. Mater. Chem. A 2013, 1, 13337-13347. [CrossRef]

12. Fu, Y.; Wei, Z.D.; Chen, S.G.; Li, L.; Feng, Y.C.; Wang, Y.Q.; Ma, X.L.; Liao, M.J.; Shen, P.K.; Jiang, S.P. Synthesis of $\mathrm{Pd} / \mathrm{TiO}_{2}$ nanotubes/Ti for oxygen reduction reaction in acidic solution. J. Power Sources 2009, 189, 982-987. [CrossRef]

13. Wu, R.; Tsiakaras, P.; Shen, P.K. Facile synthesis of bimetallic Pt-Pd symmetry-broken concave nanocubes and their enhanced activity toward oxygen reduction reaction. Appl. Catal. B Environ. 2019, 251, 49-56. [CrossRef]

14. Tzorbatzoglou, F.; Brouzgou, A.; Tsiakaras, P. Electrocatalytic activity of Vulcan-XC-72 supported Pd, Rh and PdxRhy toward HOR and ORR. Appl. Catal. B Environ. 2015, 174-175, 203-211. [CrossRef] 
15. Tzorbatzoglou, F.; Brouzgou, A.; Jing, S.; Wang, Y.; Song, S.; Tsiakaras, P. Oxygen reduction and hydrogen oxidation reaction on novel carbon supported PdxIry electrocatalysts. Int. J. Hydrog. Energy 2018, 43, 11766-11777. [CrossRef]

16. Bhatt, M.D.; Lee, J.Y. Advancement of Platinum (Pt)-Free (Non-Pt Precious Metals) and/or Metal-Free (Non-Precious-Metals) Electrocatalysts in Energy Applications: A Review and Perspectives. Energy Fuels 2020, 34, 6634-6695. [CrossRef]

17. Iglesias, D.; Giuliani, A.; Melchionna, M.; Marchesan, S.; Criado, A.; Nasi, L.; Bevilacqua, M.; Tavagnacco, C.; Vizza, F.; Prato, M.; et al. N-Doped Graphitized Carbon Nanohorns as a Forefront Electrocatalyst in Highly Selective $\mathrm{O}_{2}$ Reduction to $\mathrm{H}_{2} \mathrm{O}_{2}$. Chem 2018, 4, 106-123. [CrossRef]

18. Tuci, G.; Zafferoni, C.; Rossin, A.; Milella, A.; Luconi, L.; Innocenti, M.; Truong Phuoc, L.; Duong-Viet, C.; Pham-Huu, C.; Giambastiani, G. Chemically Functionalized Carbon Nanotubes with Pyridine Groups as Easily Tunable N-Decorated Nanomaterials for the Oxygen Reduction Reaction in Alkaline Medium. Chem. Mater. 2014, 26, 3460-3470. [CrossRef]

19. Yan, Z.; Gao, L.; Dai, C.; Zhang, M.; Lv, X.; Shen, P.K. Metal-free mesoporous carbon with higher contents of active $\mathrm{N}$ and $\mathrm{S}$ codoping by template method for superior ORR efficiency to Pt/C. Int. J. Hydrogen Energy 2018, 43, 3705-3715. [CrossRef]

20. Passaponti, M.; Rosi, L.; Savastano, M.; Giurlani, W.; Miller, H.A.; Lavacchi, A.; Filippi, J.; Zangari, G.; Vizza, F.; Innocenti, M. Recycling of waste automobile tires: Transforming char in oxygen reduction reaction catalysts for alkaline fuel cells. J. Power Sources 2019, 427, 85-90. [CrossRef]

21. Li, H.; Zhu, H.; Zhuang, Z.; Lu, S.; Duan, F.; Du, M. Single-atom catalysts for electrochemical clean energy conversion: recent progress and perspectives. Sustain. Energy Fuels 2020, 4, 996-1011. [CrossRef]

22. Zhao, D.; Zhuang, Z.; Cao, X.; Zhang, C.; Peng, Q.; Chen, C.; Li, Y. Atomic site electrocatalysts for water splitting, oxygen reduction and selective oxidation. Chem. Soc. Rev. 2020, 49, 2215-2264. [CrossRef]

23. Liu, Q.; Peng, Y.; Li, Q.; He, T.; Morris, D.; Nichols, F.; Mercado, R.; Zhang, P.; Chen, S. Atomic Dispersion and Surface Enrichment of Palladium in Nitrogen-Doped Porous Carbon Cages Lead to High-Performance Electrocatalytic Reduction of Oxygen. ACS Appl. Mater. Interfaces 2020, 12, 17641-17650. [CrossRef]

24. Passaponti, M.; Savastano, M.; Clares, M.P.; Inclán, M.; Lavacchi, A.; Bianchi, A.; García-España, E.; Innocenti, M. MWCNTs-Supported Pd(II) Complexes with High Catalytic Efficiency in Oxygen Reduction Reaction in Alkaline Media. Inorg. Chem. 2018, 57, 14484-14488. [CrossRef]

25. Godino-Salido, M.L.; Gutiérrez-Valero, M.D.; López-Garzón, R.; Arranz-Mascarós, P.; Santiago-Medina, A.; Melguizo, M.; Domingo-García, M.; López-Garzón, F.J.; Abdelkader-Fernández, V.K.; de Lecea, C.S.-M.; et al. New hybrid materials based on the grafting of $\mathrm{Pd}(\mathrm{II})$-amino complexes on the graphitic surface of AC: preparation, structures and catalytic properties. RSC Adv. 2016, 6, 58247-58259. [CrossRef]

26. López-Garzón, R.; Godino-Salido, M.L.; Gutiérrez-Valero, M.D.; Arranz-Mascarós, P.; Melguizo, M.; García, C.; Domingo-García, M.; López-Garzón, F.J. Supramolecular assembling of molecular ion-ligands on graphite-based solid materials directed to specific binding of metal ions. Inorg. Chim. Acta 2014, 417, 208-221. [CrossRef]

27. Savastano, M.; Arranz-Mascarós, P.; Bazzicalupi, C.; Clares, M.P.; Godino-Salido, M.L.; Gutiérrez-Valero, M.D.; Inclán, M.; Bianchi, A.; García-España, E.; López-Garzón, R. Construction of green nanostructured heterogeneous catalysts via non-covalent surface decoration of multi-walled carbon nanotubes with $\mathrm{Pd}(\mathrm{II})$ complexes of azamacrocycles. J. Catal. 2017, 353, 239-249. [CrossRef]

28. Savastano, M.; Arranz-Mascarós, P.; Clares, M.P.; Cuesta, R.; Godino-Salido, M.L.; Guijarro, L.; Gutiérrez-Valero, M.D.; Inclán, M.; Bianchi, A.; García-España, E.; et al. A New Heterogeneous Catalyst Obtained via Supramolecular Decoration of Graphene with a $\mathrm{Pd}^{2+}$ Azamacrocyclic Complex. Molecules 2019, 24, 2714. [CrossRef]

29. García-Martín, J.; López-Garzón, R.; Godino-Salido, M.L.; Gutiérrez-Valero, M.D.; Arranz-Mascarós, P.; Cuesta, R.; Carrasco-Marín, F. Ligand Adsorption on an Activated Carbon for the Removal of Chromate Ions from Aqueous Solutions. Langmuir 2005, 21, 6908-6914. [CrossRef]

30. Gutiérrez-Valero, M.D.; Godino-Salido, M.L.; Arranz-Mascarós, P.; López-Garzón, R.; Cuesta, R.; García-Martín, J. Adsorption of Designed Pyrimidine Derivative Ligands on an Activated Carbon for the Removal of $\mathrm{Cu}$ (II) Ions from Aqueous Solution. Langmuir 2007, 23, 5995-6003. [CrossRef] [PubMed] 
31. Savastano, M.; Arranz-Mascarós, P.; Bazzicalupi, C.; Clares, M.P.; Godino-Salido, M.L.; Guijarro, L.; Gutiérrez-Valero, M.D.; Bianchi, A.; García-España, E.; López-Garzón, R. Polyfunctional Tetraaza-Macrocyclic Ligands: $\mathrm{Zn}(\mathrm{II}), \mathrm{Cu}(\mathrm{II})$ Binding and Formation of Hybrid Materials with Multiwalled Carbon Nanotubes. ACS Omega 2017, 2, 3868-3877. [CrossRef]

32. Godino-Salido, M.L.; Santiago-Medina, A.; López-Garzón, R.; Gutiérrez-Valero, M.D.; Arranz-Mascarós, P.; López de la Torre, M.D.; Domingo-García, M.; López-Garzón, F.J. Preparation and characterization of trihydroxamic acid functionalized carbon materials for the removal of $\mathrm{Cu}(\mathrm{II})$ ions from aqueous solution. Appl. Surf. Sci. 2016, 387, 128-138. [CrossRef]

33. Luz Godino-Salido, M.; Santiago-Medina, A.; Arranz-Mascarós, P.; López-Garzón, R.; Gutiérrez-Valero, M.D.; Melguizo, M.; Javier López-Garzón, F. Novel active carbon/crown ether derivative hybrid material for the selective removal of $\mathrm{Cu}$ (II) ions: The crucial role of the surface chemical functions. Chem. Eng. Sci. 2014, 114, 94-104. [CrossRef]

34. Savastano, M.; Arranz-Mascarós, P.; Bazzicalupi, C.; Bianchi, A.; Giorgi, C.; Godino-Salido, M.L.; Gutiérrez-Valero, M.D.; López-Garzón, R. Binding and removal of octahedral, tetrahedral, square planar and linear anions in water by means of activated carbon functionalized with a pyrimidine-based anion receptor. RSC Adv. 2014, 4, 58505-58513. [CrossRef]

35. Arranz, P.; Bianchi, A.; Cuesta, R.; Giorgi, C.; Godino, M.L.; Gutiérrez, M.D.; López, R.; Santiago, A. Binding and Removal of Sulfate, Phosphate, Arsenate, Tetrachloromercurate, and Chromate in Aqueous Solution by Means of an Activated Carbon Functionalized with a Pyrimidine-Based Anion Receptor (HL). Crystal Structures of $\left[\mathrm{H}_{3} \mathrm{~L}\left(\mathrm{HgCl}_{4}\right)\right] \cdot \mathrm{H}_{2} \mathrm{O}$ and $\left[\mathrm{H}_{3} \mathrm{~L}\left(\mathrm{HgBr}_{4}\right)\right] \cdot \mathrm{H}_{2} \mathrm{O}$ Showing Anion $-\pi$ Interactions. Inorg. Chem. 2010, 49, 9321-9332. [PubMed]

36. Savastano, M.; Zoppi, C.; Bianchi, A.; Bazzicalupi, C. Synthesis and coordination properties of a new ligand designed for surface functionalization of carbon substrates. Inorg. Chim. Acta 2020, 511, 119793. [CrossRef]

37. Dietrich, B.; Hosseini, M.W.; Lehn, J.-M.; Sessions, R.B. Synthesis of Macrobicyclic Polyamines by Direct Macrobicyclisation via Tripode-Tripode Coupling. Helv. Chim. Acta 1985, 68, 289-299. [CrossRef]

38. Tei, L.; Bencini, A.; Blake, A.J.; Lippolis, V.; Perra, A.; Valtancoli, B.; Wilson, C.; Schröder, M. Co-ordination chemistry of amino pendant arm derivatives of 1,4,7-triazacyclononane. Dalton Trans. 2004, 1934-1944. [CrossRef]

39. Engelmann, M. Ueber eine Synthese des 1-Methylxanthins. Ber. der Dtsch. Chem. Ges. 1909, 42, 177-182. [CrossRef]

40. Bazzicalupi, C.; Bianchi, A.; Biver, T.; Giorgi, C.; Santarelli, S.; Savastano, M. Formation of Double-Strand Dimetallic Helicates with a Terpyridine-Based Macrocycle. Inorg. Chem. 2014, 53, 12215-12224. [CrossRef]

41. Savastano, M.; Bazzicalupi, C.; García-Gallarín, C.; de la Torre, M.D.L.; Bianchi, A.; Melguizo, M. Supramolecular forces and their interplay in stabilizing complexes of organic anions: Tuning binding selectivity in water. Org. Chem. Front. 2018, 6, 75-86. [CrossRef]

42. Fontanelli, M.; Micheloni, M. Proceedings of the I Spanish-Italian Congress on Thermodynamics of Metal Complexes; Diputación de Castellón: Castellón, Spain, 1990; pp. 41-43.

43. Savastano, M.; Fiaschi, M.; Ferraro, G.; Gratteri, P.; Mariani, P.; Bianchi, A.; Bazzicalupi, C. Sensing $\mathrm{Zn}^{2+}$ in Aqueous Solution with a Fluorescent Scorpiand Macrocyclic Ligand Decorated with an Anthracene Bearing Tail. Molecules 2020, 25, 1355. [CrossRef] [PubMed]

44. Gran, G. Determination of the equivalence point in potentiometric titrations. Part II. Analyst 1952, 77, 661-671. [CrossRef]

45. Gans, P.; Sabatini, A.; Vacca, A. Investigation of equilibria in solution. Determination of equilibrium constants with the HYPERQUAD suite of programs. Talanta 1996, 43, 1739-1753. [CrossRef]

46. Borri, C.; Calisi, N.; Galvanetto, E.; Falsini, N.; Biccari, F.; Vinattieri, A.; Cucinotta, G.; Caporali, S. First Proof-of-Principle of Inorganic Lead Halide Perovskites Deposition by Magnetron-Sputtering. Nanomaterials 2020, 10, 60. [CrossRef] [PubMed]

47. Calisi, N.; Caporali, S.; Milanesi, A.; Innocenti, M.; Salvietti, E.; Bardi, U. Composition-Dependent Degradation of Hybrid and Inorganic Lead Perovskites in Ambient Conditions. Top. Catal. 2018, 61, 1201-1208. [CrossRef]

48. Muniz-Miranda, M.; Muniz-Miranda, F.; Caporali, S.; Calisi, N.; Pedone, A. SERS, XPS and DFT investigation on palladium surfaces coated with 2,2'-bipyridine monolayers. Appl. Surf. Sci. 2018, 457, 98-103. [CrossRef] 
49. Anderegg, G.; Wanner, H. Pyridine derivatives as complexing agents. XIII. The stability of the palladium(II) complexes with pyridine, 2,2'-bipyridyl, and 1,10-phenanthroline. Inorg. Chim. Acta 1986, 113, 101-108. [CrossRef]

50. Lari, L.; Nuttall, C.J.; Copley, M.P.; Potter, R.J.; Simon, J.; Mingo, N.; Ozkaya, D. Characterization of nanoembedded alloyed thermoelectrics. J. Phys. Conf. Ser. 2014, 522, 012040. [CrossRef]

51. López-Garzón, R.; Arranz-Mascarós, P.; Godino-Salido, M.L.; Gutiérrez-Valero, M.D.; Cuesta, R.; Moreno, J.M. Bifunctional pyrimidine-amino-acid ligands: Solution study and crystal structure of a $\mathrm{Mn}(\mathrm{II})$ chain alternating six- and sevenfold coordination environments. Inorg. Chim. Acta 2003, 355, 41-48. [CrossRef]

52. López-Garzón, R.; Godino-Salido, M.L.; Arranz-Mascarós, P.; Fontecha-Cámara, M.A.; Gutiérrez-Valero, M.D.; Cuesta, R.; Moreno, J.M.; Stoeckli-Evans, H. Protonation and $\mathrm{Zn}(\mathrm{II})$ complexation with versatile valine and glycylglycine N-pyrimidines derivatives: crystal structures of layered $\left\{\left[\mathrm{Zn}(\mathrm{HL} 1)_{2}\right] \cdot 2 \mathrm{H}_{2} \mathrm{O}\right\} \mathrm{n}$ and [Zn(HL2 $\left.)_{2}\left(\mathrm{H}_{2} \mathrm{O}\right)_{4}\right]$. Inorg. Chim. Acta 2004, 357, 2007-2014. [CrossRef]

Publisher's Note: MDPI stays neutral with regard to jurisdictional claims in published maps and institutional affiliations.

(C) 2020 by the authors. Licensee MDPI, Basel, Switzerland. This article is an open access article distributed under the terms and conditions of the Creative Commons Attribution (CC BY) license (http://creativecommons.org/licenses/by/4.0/). 